\title{
The relationship between talent management, transformational leadership and work engagement: An automotive artisan perspective
}

\begin{tabular}{|c|c|}
\hline \multicolumn{2}{|c|}{$\begin{array}{l}\text { Authors: } \\
\text { Pieter K. Smit }{ }^{1} \text { (D) } \\
\text { Cecile M. Schultz } \\
\text { Catharina E. van Hoek }{ }^{1} \text { (D) }\end{array}$} \\
\hline \multicolumn{2}{|c|}{$\begin{array}{l}\text { Affiliations: } \\
{ }^{1} \text { Department of People } \\
\text { Management and } \\
\text { Development, Faculty } \\
\text { Management Sciences, } \\
\text { Tshwane University of } \\
\text { Technology, Pretoria, } \\
\text { South Africa }\end{array}$} \\
\hline \multicolumn{2}{|c|}{$\begin{array}{l}\text { Corresponding author: } \\
\text { Pieter Smit, } \\
\text { smitpk@tut.ac.za }\end{array}$} \\
\hline \multicolumn{2}{|c|}{$\begin{array}{l}\text { Dates: } \\
\text { Received: } 19 \text { Feb. } 2021 \\
\text { Accepted: } 23 \text { Aug. } 2021 \\
\text { Published: } 28 \text { Oct. } 2021\end{array}$} \\
\hline \multicolumn{2}{|c|}{$\begin{array}{l}\text { How to cite this article: } \\
\text { Smit, P.K., Schultz, C.M., } \\
\text { \& Van Hoek, C.E. (2021). The } \\
\text { relationship between talent } \\
\text { management, } \\
\text { transformational leadership } \\
\text { and work engagement: An } \\
\text { automotive artisan } \\
\text { perspective. SA Journal of } \\
\text { Human Resource } \\
\text { Management/SA Tydskrif } \\
\text { vir Menslikehulpbronbestuur, } \\
\text { 19(0), a1578. https://doi. } \\
\text { org/10.4102/sajhrm. } \\
\text { v19i0.1578 }\end{array}$} \\
\hline \multicolumn{2}{|c|}{$\begin{array}{l}\text { Copyright: } \\
\text { (C) 2021. The Authors. } \\
\text { Licensee: AOSIS. This } \\
\text { is licensed under the } \\
\text { Creative Commons } \\
\text { Attribution License. }\end{array}$} \\
\hline \multicolumn{2}{|l|}{ Read online: } \\
\hline 回: & $\begin{array}{l}\text { Scan this QR } \\
\text { code with your } \\
\text { smart phone or } \\
\text { mobile device } \\
\text { to read online. }\end{array}$ \\
\hline
\end{tabular}

Orientation: Understanding the relationship between talent management, transformational leadership and work engagement from an automotive artisan perspective within South Africa.

Research purpose: The purpose was to determine the relationship between talent management, transformational leadership and work engagement from an automotive artisan perspective within South Africa.

Motivation of the study: Most talent management focuses on understanding the role of the manager, with very little research being dedicated to understanding the effect of talent management on work engagement and transformational leadership amongst South African artisans.

Research approach/design and method: A survey was conducted amongst a non-probability sample of 609 artisans from a population of 1045 artisans. A quantitative research approach was used, and structural equation modelling was used to analyse the data.

Main findings: The results showed that talent management acted as a mediator between the transformational leadership and work engagement of artisans in the automotive industry. There were positive relationships between talent management and work engagement and between talent management and transformational leadership, but not between transformational leadership and work engagement.

Practical and managerial implications: A strategic approach should be implemented that will drive a talent management process with clear rewards and recognition for all stakeholders. This approach should be a part of the business rhythm, business agendas, organisational processes and culture of the industry. Should talent management, as a mediator, not form a part of work engagement and transformational leadership in the automotive industry, these variables will not function properly.

Contribution/value addition: Talent management offers a bridge between the two variables of transformational leadership and work engagement. It was clear in this study that a focus on talent management within the automotive industry is pivotal.

Keywords: transformational leadership; work engagement; talent management; artisans; automotive industry.

\section{Introduction}

\section{Background and contextualisation of the study}

Sharma and Naude (2021) state that the South African automotive industry, which is the most significant sector in the South African economy, needs to function efficiently to compete globally. The gross domestic product (GDP) of a country is one of the main indicators used to measure the performance of a country's economy (StatsSA, 2021). The automotive industry is currently a significant contributor to South African GDP (6.8\%), with 110000 people employed across vehicle and component manufacturers. It also has an estimated indirect impact on 1.5 million people (BusinessTech, 2021). In South Africa, the artisan occupation is facing two important issues: the need for expansion and the need for transformation (Teti, 2016). There are widespread claims of a shortage of artisans in South Africa as well as a general agreement that artisan development is crucial (Wildschut \& Ralphs, 2016).

Hufkie (2021) states that reskilling of artisans within the automotive industry in South Africa is needed towards Fourth Industrial Revolution (4IR) readiness. Many South African artisans are 
being deskilled and the remaining artisans are being reshuffled to assembly lines likely to be automated with time (Chigbu \& Nekhwevha, 2020). The study of Mey, Poisat and Stindt (2021, p. 1) revealed that:

$[T]$ he retention of skilled, engaged employees requires leaders who can provide them with a sense of belonging, respect, empowerment, support their personal growth and development, and provide them with flexibility and freedom in executing their duties. (p. 1)

Leadership support is vital in endorsing an enabling environment that cultivates talent. Without leadership's utilisation of opportunities to provide an enabling environment, talent is not secured and will not thrive (Shikweni, Schurink, \& Van Wyk, 2019). A transformation leadership style within the South African automotive industry will, therefore, be needed to develop interventions to manage the talent of artisans and to increase their work engagement.

\section{Research gap and purpose}

It is essential that a culture is created where talent and engagement can emerge, and where leaders and managers are willing to put practices in place to ensure the development of talented and engaged employees (Savarimuthu \& Jothi, 2020). Real leadership is needed in the automotive industry's competitive environment to guide subordinates so that they share goals, attitudes, values, and work towards the achievement of organisational strategies (Gautam \& Enslin, 2019). Leaders also need to stimulate employees' work engagement through progressive policies and work practices (Decuypere \& Schaufeli, 2020). By combining research about talent management, leadership and work engagement, it is possible for managers to develop strategies and approaches to work engagement and talent management that become self-reinforcing. However, such studies conducted in the South African automotive industry from an artisan perspective are not known. This study is, therefore, conducted to close this research gap by investigating the relationship between talent management, transformational leadership and work engagement within the automotive industry from an artisan perspective. Furthermore, it is hoped that this study will contribute to an in-depth understanding of the intervening effect that talent management has on transformational leadership and work engagement.

\section{Literature review}

The underpinning theory used in this study was the ability, motivation and opportunity (AMO) theory. According to AMO theory, the components of ability, motivation and opportunity are the three-independent work-system elements that form employee characteristics and eventually lead to organisational success (Shanaz, Dlvin, \& Vala, 2020). Ability refers to those practices and policies to ensure that employees obtain the required skills, knowledge and ability to perform their tasks with minimum supervision (Yahya, Tan, \& Tay, 2017). Motivation refers to employee performance and the extra efforts that employees put into their jobs (Yahya et al., 2017). The last component is the opportunity-enhancing human resources management (HRM) practices which aim at engaging employee involvement by providing opportunities (Yahya et al., 2017).

Saks and Gruman (2017) propose that drawing from the AMO theory will enable researchers to understand how HRM practices can influence work engagement. Amor, Vázquez and Faíña (2020) stated that managers should be aware of the critical role of the leader in stimulating work engagement. Organisational interventions that promote the development of transformational leadership may be valuable to enhance work engagement. Whilst organisations need to recruit and retain top talent, they also need their talented employees to be engaged in their work (Bakker \& Leiter, 2010).

\section{Transformational leadership}

The theory of transformational leadership was first coined by Downton (1973). Downton (1973) categorised three leadership tendencies, which are transactional leadership, charismatic leadership and inspirational leadership. Avolio, Waldman and Yammarino (1991) mentioned the four I's of transformational leadership namely, idealised influence (modelling ethical and socially desirable behaviour, exhibiting enthusiasm about company strategy), inspirational motivation (to impart a vision that is appealing and worthy), intellectual stimulation (empowering employees to constantly be learning) and individualised consideration (giving employees a feeling of ownership in company goals and independence in the workplace).

Idealised influence is described by Hamidianpour, Esmaeilpour and Mashayekh (2016), wherein followers demonstrate respect and loyalty towards a leader who conveys an ideal sense and makes followers consider the leader as a perfect sense model of behaviour. Inspirational motivation is defined by Steinmann, Klug and Maier (2018) as the method in which a transformational leader inspirationally motivates followers to achieve more than expected by sharing his or her vision in order to inspire them towards a more effective and efficient performance of their duties. Intellectual stimulation refers to the leader's ability to instil innovative and creative capabilities into followers as a way of building their critical thinking and problemsolving skills (Atiku \& Anane-Simon, 2020). Individualised consideration is a dimension of transformational leadership whereby a leader pays special attention to individual differences, followers' personal growth and needs for achievement by acting as a mentor or coach for them (Gonfa, 2019).

Swanwick (2017) opined that developing transformational leadership with training in the four I's can enhance a leader's effectiveness and satisfaction. Khorshid and Pashazadeh (2014) maintained that transformational leaders create an atmosphere of trust and motivate employees to work for the organisation beyond their self-interests. Transformational leadership has proven to be a pervasive model, inspiring shared purpose, engaging others and 
sharing the vision of an organisation (Swanwick, 2017). Mittal and Dhar (2015) also put forth the fact that a transformational leader is one who inspires followers to do more than originally expected.

\section{Talent management}

Lewis and Heckman (2006) mentioned that there are three distinct perspectives regarding talent management. The first perspective defines talent management as a collection of typical human resource department practices, functions, activities or specialist areas such as recruiting, selection, development and career and succession management (Mercer, 2005). The second perspective on talent management focuses primarily on the concept of talent pools by focusing on the internal workforce (Schweyer, 2004). Employees who experience a talent management system that is based on an inclusive or stable philosophy are likely to feel supported and valued by their organisation because they work in surroundings that are generally appreciative of their talents (Meyers \& Van Woerkom, 2014). A third perspective on talent management focuses on high performing talent (Axelrod, Handfield-Jones, \& Michaels, 2002) on the one hand and generic talent (Walker \& Larocco, 2002) on the other hand.

New perspectives on talent management by Rhodes and Fletcher (2013) bring approaches that are focused on both the employment and the work relationship and that consider the influence and well-being of role players at multiple levels. Talent management is an integrated, strategic and deliberate activity that is performed to direct how organisations source, attract, select, train, develop, retain, promote and deploy employees (Van Rooyen \& Whittle, 2011). Johnson (2015) posits that talent management is about the early identification of key role players and articulation of duties, leading to ownership and clear accountability to ensure organisational success. Ogbari, Onasanya, Ogunnaike and Kehinde (2018) are of the opinion that one of the main components of talent management is continuously training personnel to maintain the required level of performance. Talent management contributes to creating a high-performance work culture within an organisation (Poisat et al., 2018).

\section{Work engagement}

Work engagement refers to a positive, affective-motivational state of high energy combined with high levels of dedication and a strong focus on work (Schaufeli \& Bakker, 2010). Engaged employees demonstrate vigour, dedication and absorption when executing tasks in the workplace (Schaufeli, Salanova, Gonzáles-Romá, \& Bakker, 2002). Dedication and vigour are regarded as the core components of work engagement (Schaufeli, 2013; Taris, Ybema, \& Van Beek, 2017). Vigour means enhanced levels of mental resilience and energy and includes employees' preparedness to put effort into their work (Schaufeli, Martinez, Pinto, Salanova, \& Bakker, 2002; Sonnentag, 2017). Employees with dedication feel challenged, proud, inspired and enthusiastic, and experience a sense of significance about their work (Schaufeli et al., 2002a; Sonnentag, 2017). Absorption entails the immersion in one's work (Schaufeli et al., 2002b).

Individuals who are engaged in their work have high levels of energy, are enthusiastic about their work and are completely immersed in their work activities (Bakker \& Albrecht, 2018). The majority of studies have adopted a between-person approach, showing that there are mean level differences in work engagement between individuals as a function of working conditions, personal characteristics and behavioural strategies (Bakker, Demerouti, \& Sanz-Vergel, 2014).

\section{Development of the hypotheses}

In this study, nine research hypotheses were developed and investigated. The development of each of these hypotheses is discussed in the following sections.

\section{Talent management and transformational leadership}

According to the research conducted by Ghafoor, Qureshi, Khan and Hijazi (2011), transformational leadership was positively related to talent management. Transformational leadership has an effect on talent management (Onyango, 2015). Widodo and Mawarto (2020) found that there is a significant relationship between talent management and transformational leadership.

The relationship between transformational leadership and talent management highlighted the following hypotheses:

Hypothesis 1: Talent management (performance planning and motivational processes) will be positively related to transformational leadership.

Hypothesis 2: Talent management (career development) will be positively related to transformational leadership.

\section{Talent management and work engagement}

According to research conducted by Church (2013), talent management positively relates to work engagement. The findings of Sopiah, Kurniawan, Nora and Narmaditya (2020) confirmed that talent management positively influences work involvement and employee performance. There is a significant positive relationship between talent management and work engagement (Toka \& Hamida, 2020). Ishayama (2021) found that talent management has an impact on work engagement.

The relationship between work engagement and talent management highlighted the following hypotheses:

Hypothesis 3: Talent management (performance planning and motivational processes) will be positively related to work engagement (vigour).

Hypothesis 4: Talent management (career development) will be positively related to work engagement (vigour). 
Hypothesis 5: Talent management (performance planning and motivational processes) will be positively related to work engagement (dedication).

Hypothesis 6: Talent management (career development) will be positively related to work engagement (dedication).

\section{Work engagement and transformational leadership}

A positive leadership style, such as transformational leadership, has a relatively large correlation with work engagement (Hoch, Bommer, Dulebohn, \& Wu, 2018). The findings of Gautam and Enslin (2019) indicated that transformational leadership moderately influenced work engagement more than transactional leadership and there was a positive relationship between these two constructs. An increasing number of studies suggests that transformational leadership influences work engagement (Breevaart et al., 2014; Tims, Bakker, \& Xanthopoulou, 2011; Tuckey, Bakker, \& Dollard, 2012). Leadership styles can potentially complement the known benefits associated with transformational leadership, particularly in explaining the emergence and maintenance of engagement in dynamic team-based working contexts (Bakker \& Albrecht, 2018). Hayati, Charkhabi and Naami's (2014) investigation of transformational leadership suggested that transformational leadership would likely be the most predictive characteristic of an optimal leader. In support of this statement, Avolio, Bass and Jung (1999) stated that transformational leaders embody characteristics of being charismatic and influential in their ability to make employees do more than expected at work.

The relationship between work engagement and transformational leadership highlighted the following hypotheses:

Hypothesis 7: Work engagement (vigour) will be positively related to transformational leadership.

Hypothesis 8: Work engagement (dedication) will be positively related to transformational leadership.

\section{Talent management, transformational leadership and work engagement}

According to Lai et al. (2020), work engagement mediates the relationship between transformational leadership and employees' task performance and helping behaviour. In addition, transformational leaders can enhance followers' performance and foster their helping behaviours because they induce members' work engagement and enable them to exceed expectations. Furthermore, Lai et al.'s (2020) research also depicted that role-based self-efficacy, transactional leadership and work engagement fully mediate the positive relationship between transformational leadership and members' task performance and helping behaviours (Lai et al., 2020). Sopiah et al. (2020) found that work engagement had a moderating role between talent management and employee performance.

Talent management as a mediator between transformational leadership and work engagement highlighted the following hypothesis:

Hypothesis 9: Talent management mediates transformational leadership and work engagement.

A graphic presentation of the hypotheses is presented in Figure 1.

\section{Method \\ Research method}

Empirical research, which was conducted in this study, should primarily be embedded in theory. For the purpose of this study, current, proven and tested questionnaires on the variables of transformational leadership, talent management and work engagement were used. In other words, data were directly collected from the sample group. From the analysis of the statistical data gathered, conclusions were drawn.

\section{Research context}

This study was conducted at a large organisation that provides training to all artisans in the South African automotive

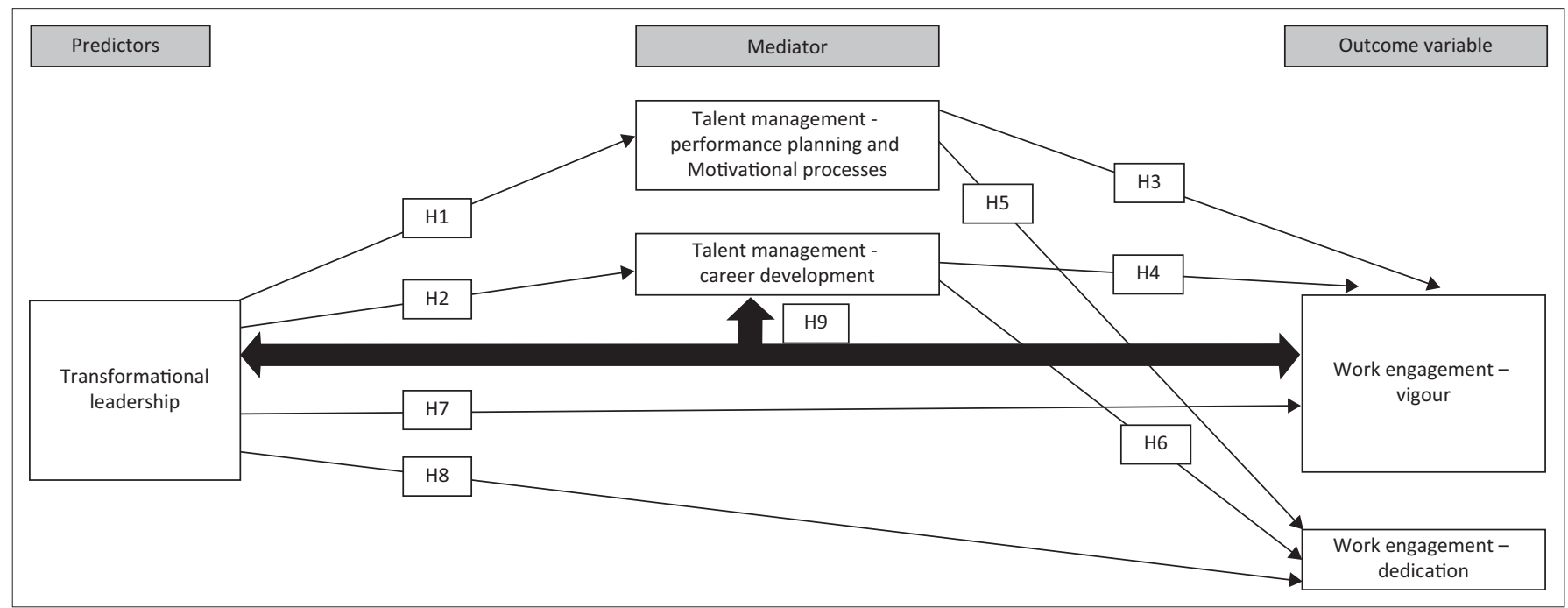

FIGURE 1: Hypothesised relationships and conceptual model. 
industry. Automotive organisations were represented by automotive brands selling vehicles in all nine provinces in South Africa. From a total of 1045 artisans targeted, 609 respondents completed the questionnaire on transformational leadership, talent management and work engagement.

\section{Sample}

For the purpose of this research, artisans from 152 automotive South African organisations were targeted to complete the questionnaire. Purposive sampling was used to target the artisans who attended training at three different training venues at a specific point in time.

\section{Research approach and design}

The study takes the ontological position of objectivism, with a positivistic epistemology. According to Botma, Greeff, Mulaudzi and Wright (2010), epistemology determines the methodologies, theories and procedure application throughout the research process. Therefore, a quantitative and non-experimental research approach was adopted. Leedy and Ormrod (2016) highlighted that descriptive quantitative research entails the identification and exploration of characteristics of the phenomenon and possible correlations amongst the multiple phenomena. A self-administered questionnaire survey design was utilised for data collection purposes. Cross-sectional and survey research designs were used in this study.

\section{Research instrument}

Thefollowing instruments discussed namely, transformational leadership, talent management and work engagement are those that were used in the study.

\section{Transformational leadership measurement}

According to Bass and Riggio (2006), the most widely accepted instrument to measure transformational leadership is the Multifactor Leadership Questionnaire (MLQ), which assesses the Full Range of Leadership (FRL) model, including laissezfaire leadership, the components of transactional leadership, namely management by exception (both active and passive forms) and contingent reward, as well as components of transformational leadership. In the study of Louw, Muriithi and Radloff (2017), the Cronbach's alpha assessment was done to establish the reliability of the scales of the measuring instrument and the scores were considered very reliable compared to the minimum acceptable score of 0.7 (Nunnally, 1978). For all factors, coefficients of greater than 0.7 (Nunnally, 1978 , p. 226) were returned. Sufficient evidence of validity and reliability for the scales measuring the independent and dependent variables is thus provided. The specific scores for transformational leadership sub-constructs were: individualised consideration (0.892), idealised influence behaviour (0.844), inspirational motivation (0.868), intellectual simulation (0.869) and idealised influence attributes (0.849). The alpha scores were in agreement with similar studies, thereby making the measuring instrument and data reliable (Hayward, 2005).

\section{Talent management measurement}

A questionnaire on talent management was adapted from Van Hoek (2014), it consisted of 29 questions. The instrument was previously used in the study conducted by (Van Hoek 2014). In this study of Van Hoek (2014), performance management obtained the Cronbach's alpha value of 0.845 , however remuneration obtained Cronbach's alpha of 0.619, finally career development obtained the Cronbach's alpha value of 0.629. The Cronbach's alpha should be more than 0.70 to make the scale more reliable, in this case two factors, that is, remuneration and career development obtained the Cronbach's alpha value just below the acceptable level and performance management obtained an acceptable level of 0.845 of the Cronbach's alpha value, that made the scale more reliable (Van Hoek, 2014).

\section{Work engagement measurement}

Schaufeli et al. (2006) set out to develop a short questionnaire to measure work engagement and validate its scores. This questionnaire was used in this research to measure engagement. In the study of Hoole and Bonnema (2015), Cronbach's alpha scores of 0.93 and 0.72 were obtained for the Utrecht Work Engagement Scale (UWES) and Performance management system (PMS), respectively. In the case of the PMS, one should take into consideration that reliability also tends to be lower when a scale consists of fewer than 10 items (Pallant, 2005).

\section{Data collection procedure}

The questionnaires which are in English were manually distributed to the artisans. Sealed boxes were used for collection in order to ensure anonymity and confidentially. The returned responses with missing values were excluded from the analysis.

\section{Data analysis}

The Stata version 15 statistical analysis software was used for the analysis of data. Descriptive statistics were reported in a form of frequencies and percentages. In terms of inferential statistics, the structural equation modelling (SEM) using the partial least squares path modelling approach (PLS-PM) was performed (Hair, Sarstedt, Hopkins, \& Kuppelwieser, 2014). Bootstrapping was used to estimate the parameters and associated standard errors in the direct and indirect effect in the statistical analysis of the structural equation model through the non-parametric method.

\section{Measurement model evaluation}

Measurement model evaluation is aimed to evaluate the consistency and validity of the manifest variables. Consistency evaluations are through individual manifest and construct reliability tests. Whilst validity of the variables is tested based on convergent and discriminant validity, individual manifest reliability explains the variance of individual manifest relative 
to latent variable by calculating standardised outer loadings of the manifest variable. Structural equation modelling consists of two parts, namely the measurement model evaluation and the testing of the structural model. Measurement model evaluation is intended to evaluate the validity and consistency of the manifest variables. Validity of the variables is tested based on convergent and discriminant validity, and individual manifest reliability explains the variance of individual manifest relative to latent variable by calculating standardised outer loadings of the manifest variable, whilst consistency evaluations are done through individual manifest and construct reliability tests.

\section{Ethical considerations}

Approval was granted by the automotive industry to conduct research on this topic with their artisans. The study was conducted within the approved ethical framework. The participation by respondents was voluntary, and their completed questionnaires were treated as confidential. Permission to conduct this study was obtained from the company under study. Ethical permission was obtained from the High ethical standards that were followed in all aspects of the research process. All possible respondents were provided with an overview of the study, before inviting them to voluntarily participate. Participants were assured of the anonymity and confidentiality of their responses and were informed that they could withdraw from the study at any stage, should they feel it necessary to do so. All participants indicated their consent.

\section{Results \\ Descriptive statistics}

A total of 609 respondents participated in the study, and the response rate was $100 \%$. The data revealed that there were more male respondents $(96.72 \%)$ than female respondents (3.28\%) who participated in the study. The data show that most respondents were Africans with $43.64 \%$, followed by their white counterparts with $31.74 \%$, mixed races represented $15.87 \%$ and the remaining $876 \%$ represented Indian participants. Thirty-four (34) $(5.6 \%)$ were in the age group of $31-40$ years, $13(2.1 \%)$ were in the age group of $41-50$ years and only $2(0.3 \%)$ were over the age of 51 years. With regard to the education of the respondents, the majority of the respondents $(56.83 \%)$ had grade $12 \%$ and $17.7 \%$ possessed an N4-N6 qualification. In terms of tenure, the data showed that $77.80 \%$ of the respondents who completed the questionnaire had a tenure of service between 1 and 5 years, $14.50 \%$ of the respondents had a tenure of service less than 1 year, $5.9 \%$ of the respondents had a tenure of service between 6 and 10 years of service, 1\% of the respondents had a tenure of service between 11 and 20 years of service, $0.3 \%$ of the respondents had a tenure of service between 21 and 30 years of service and $0.50 \%$ of the respondents had a tenure of service more than 31 years. The percentage distribution of vehicle petrol mechanics was $78.9 \%$ compared to vehicle diesel mechanics representing
TABLE 1: Final model: Revised assessment of internal consistency.

\begin{tabular}{lcccc}
\hline Variable & $\begin{array}{c}\text { Number of } \\
\text { items }\end{array}$ & $\begin{array}{c}\text { Cronbach's } \\
\text { alpha }\end{array}$ & $\begin{array}{c}\text { Composite } \\
\text { reliability }\end{array}$ & $\begin{array}{c}\text { Average } \\
\text { variances } \\
\text { extracted }\end{array}$ \\
\hline $\begin{array}{l}\text { Performance planning } \\
\text { and motivational } \\
\text { processes }\end{array}$ & 16 & 0.954 & 0.958 & 0.588 \\
TM1 & & & & \\
Career development & 4 & 0.751 & 0.848 & 0.571 \\
TM2 & & & & \\
Leadership & 21 & 0.977 & 0.978 & 0.678 \\
TL & & & & \\
Vigour & 5 & 0.903 & 0.903 & 0.648 \\
WE1 & & & & \\
Dedication & 5 & 0.851 & 0.851 & 0.588 \\
WE2 & & & & \\
\hline
\end{tabular}

$\mathrm{TL}$, transformational leadership; WE, work engagement; TM, talent management.

$18.5 \%$, vehicle spray painter $1 \%$ and the other individual fields of work less than $1 \%$ each.

\section{Factor and reliability analysis}

The results presented in Table 1 show that the Cronbach's alpha values for all the variables are between the cut-off points of 0.5 and 0.7. Dillon-Goldstein's rho for all the variables was above 0.7 that indicates homogeneity of the factor. The results suggest that all the variables are reliable with regard to internal consistency. The quality of a measurement model was examined by testing the convergent validity, which shows the degree to which the indicators under the constructs are related. Convergent validity shows the amount of variance the indicators have in common: high factor loading and average variance extracted (AVE). According to Hair et al. (2014), AVE loadings above 0.5 are indicators of convergent validity. The results displayed in Table 1 indicate that the AVE loadings were above 0.5 , except for continuance commitment with 0.3 . The final model factor loadings are also reported in Table 1.

\section{Structural equation model results}

The direct effect in the statistical analysis of the structural equation model was determined through the non-parametric method. In the analysis of the non-parametric method, the identification of a loading close to 1 indicates a strong relationship, with the Perc 0.975 equal to a $95 \%$ confidence interval. Further loadings with a zero involved in the reading of the interval $(-0.068: 0.154)$ become insignificant. Furthermore, bootstrapping was used to estimate the parameters and associated standard errors. Table 2 indicates the different paths resulting from the statistical results (see Figure 2). TM1 is significantly related to TL. The relationship is strong and positive. This means that, when TM1 increases, TL also increases. Similarly, TM2 is significantly related to TL; however, the relationship is weak. TM1 has a moderate and positive relationship with WE1 and WE2; however, it is not as strong as with TL. Should TM1 increase, WE1 and WE2 increase. Furthermore, the results show that TM1 is a better predictor of TL than TM2. The relationship between TL and both WE1 and WE2 is not significant. The effect of TL on WE 
as a whole is not significant. TM2 is significantly related to WE1 and WE2. The relationship is strong and positive. Talent management is significantly related to TL, but not as strongly as to WE1 and WE2. Transformational leadership is not significantly related to WE1 and WE2. The relationship is very weak and not positive.

Bootstrapping was used to estimate the parameters and associated standard errors in the direct and indirect effect in the statistical analysis of the structural equation model using the non-parametric method. Table 3 indicates the total effect of the different paths from the direct and indirect statistical results. TM1 is still significantly related to TL. This relationship is positive. This means that, when TM1 increases, TL also increases. Similarly, TM2 is significantly related to $\mathrm{TL}$, but this relationship is not as positive as the direct estimation analysis only. However, the relationship between TM2 and TL is still weak. The results show that TM1 is still a better predictor of TL compared to TM2. The relationship between TL and both WE1 and WE2 is low and weak and thus not significant. The low and weak effect of TL on WE as a whole is not significant. Goodness of fit (GoF) can be used as a global criterion that helps to evaluate the performance of the model in both the inner and the outer models. Basically, GoF assesses the overall prediction performance of the model. The

TABLE 2: Direct relationship estimation of parameters and associated standard errors.

\begin{tabular}{|c|c|c|c|c|c|c|c|}
\hline \multicolumn{3}{|c|}{ Mediators } & \multirow{2}{*}{$\begin{array}{c}\begin{array}{c}\text { Original } \\
\text { loading }\end{array} \\
0.72409414\end{array}$} & \multirow{2}{*}{$\begin{array}{l}\text { Mean boot } \\
0.72597449\end{array}$} & \multirow{2}{*}{$\begin{array}{c}\text { Std error } \\
0.02608028\end{array}$} & \multirow{2}{*}{$\begin{array}{c}\text { Perc. } 025 \\
0.67356986\end{array}$} & \multirow{2}{*}{$\begin{array}{l}\text { Perc. } 975 \\
0.7737965\end{array}$} \\
\hline TL & $>$ & TM1 & & & & & \\
\hline TL & $>$ & TM2 & 0.58680133 & 0.58605348 & 0.02926914 & 0.53000248 & 0.6397414 \\
\hline TL & $>$ & WE1 & 0.02162873 & 0.02363988 & 0.04785017 & -0.07873829 & 0.1019443 \\
\hline TL & $>$ & WE2 & 0.05109092 & 0.05379507 & 0.05758874 & -0.05753642 & 0.1638507 \\
\hline TM1 & $>$ & WE1 & 0.36431031 & 0.36366077 & 0.06085257 & 0.23125139 & 0.4971365 \\
\hline TM1 & $>$ & WE2 & 0.22758160 & 0.22612395 & 0.07108644 & 0.10812951 & 0.3629391 \\
\hline TM2 & $>$ & WE1 & 0.26772774 & 0.26667119 & 0.05206934 & 0.17501043 & 0.3851303 \\
\hline TM2 & $>$ & WE2 & 0.20570264 & 0.20904856 & 0.05288084 & 0.11069119 & 0.3107307 \\
\hline
\end{tabular}

$\mathrm{TL}$, transformational leadership; $\mathrm{WE}$, work engagement; $\mathrm{TM}$, talent management. main drawback with the GoF index is that there is no threshold that allows one to determine its statistical significance. Unfortunately, there is also no guidance about what number could be considered a good GoF value. GoF can be considered as an index of average prediction for the entire model. Although this is not entirely true, it helps in understanding GoF values. The calculated global GoF is 0.479 , which exceeds the threshold of 0.36 suggested by Wetzels, OdekerkenSchröder and Van Oppen (2009). This led the researchers to conclude that the research model has a good overall fit.

\section{Discussion of the findings}

The purpose was to determine the relationship between talent management, transformational leadership and work engagement from an automotive artisan perspective within South Africa.

Transformational leadership is negatively related to work engagement. This deviates with the findings of Church (2013), Sopiah et al. (2020), Toka and Hamida (2020) and Ishayama (2021).

Talent management is positively related to transformational leadership. This concurs with the findings of Ghafoor et al. (2011), (Onyango, 2015) and Widodo and Mawarto (2020). Work engagement is negatively related to transformational leadership. This deviates with the findings of Hoch et al.

TABLE 3: Total effect estimation of parameters and associated standard errors.

\begin{tabular}{lcccccc}
\hline \multicolumn{1}{l}{ Mediators } & $\begin{array}{c}\text { Original } \\
\text { loading }\end{array}$ & Mean boot & Std error & Perc. 025 & Perc. 975 \\
\hline TL > TM1 & 0.7240941 & 0.7259745 & 0.02608028 & 0.6735699 & 0.7737965 \\
$\mathrm{TL}>\mathrm{TM} 2$ & 0.5868013 & 0.5860535 & 0.02926914 & 0.5300025 & 0.6397414 \\
$\mathrm{TL} \quad>$ WE1 & 0.4425267 & 0.4444613 & 0.03292257 & 0.3752951 & 0.5004564 \\
$\mathrm{TL}$ & $>$ WE2 & 0.3365880 & 0.3407188 & 0.04040461 & 0.2635713 & 0.4199200 \\
$\mathrm{TM} 1$ > WE1 & 0.3643103 & 0.3636608 & 0.06085257 & 0.2312514 & 0.4971365 \\
$\mathrm{TM} 1$ > WE2 & 0.2275816 & 0.2261239 & 0.07108644 & 0.1081295 & 0.3629391 \\
$\mathrm{TM} 2$ > WE1 & 0.2677277 & 0.2666712 & 0.05206934 & 0.1750104 & 0.3851303 \\
$\mathrm{TM} 2$ > WE2 & 0.2057026 & 0.2090486 & 0.05288084 & 0.1106912 & 0.3107307 \\
\hline
\end{tabular}

$\mathrm{TL}$, transformational leadership; $\mathrm{WE}$, work engagement; $\mathrm{TM}$, talent management.

\begin{tabular}{|c|c|c|c|c|c|c|c|c|}
\hline Factor & \multicolumn{2}{|c|}{ Sub-factor } & Loading & Influence & Loading & \multicolumn{2}{|r|}{ Sub-factor } & Factor \\
\hline $\begin{array}{l}\text { Iranstormational } \\
\text { leadership }\end{array}$ & & TL & & & & TL & & $\begin{array}{l}\text { Iranstormational } \\
\text { leadership }\end{array}$ \\
\hline \multirow[t]{2}{*}{$\begin{array}{c}\text { Talent } \\
\text { management }\end{array}$} & $\begin{array}{c}\text { Performance } \\
\text { planning } \\
\text { and motivational } \\
\text { processes }\end{array}$ & TM1 & & & 0.725 & TM1 & $\begin{array}{c}\text { Performance } \\
\text { planning } \\
\text { and motivational } \\
\text { processes }\end{array}$ & \multirow{2}{*}{$\begin{array}{l}\text { Talent } \\
\text { management }\end{array}$} \\
\hline & $\begin{array}{c}\text { Career } \\
\text { development }\end{array}$ & TM2 & & & 0.586 & TM2 & $\begin{array}{c}\text { Career } \\
\text { development }\end{array}$ & \\
\hline \multirow{3}{*}{$\begin{array}{c}\text { Work } \\
\text { engagement }\end{array}$} & Vigour & WE1 & & & 0.363 & WE1 & Vigour & \multirow{3}{*}{$\begin{array}{c}\text { Work } \\
\text { engagement }\end{array}$} \\
\hline & \multirow{2}{*}{ Dedication } & \multirow{2}{*}{ WE2 } & 0.053 & & 0.226 & \multirow{2}{*}{ WE2 } & \multirow{2}{*}{ Dedication } & \\
\hline & & & 0.340 & & 0.209 & & & \\
\hline
\end{tabular}

FIGURE 2: The different paths of influence from statistical results. 
(2018), Gautam and Enslin (2019), Breevaart et al. (2014), Tims et al. (2011), Tuckey et al. (2012), Bakker and Albrecht (2018) and Hayati et al. (2014). Talent management acts as the mediator between transformational leadership and work engagement. This deviates with the study of Lai et al. (2020) where work engagement mediated the relationship between transformational leadership and employees' task performance and helping behaviour. The study of Sopiah et al. (2020) found that work engagement had rather a moderating role between talent management and employee performance.

Transformational leadership provides a better fit for leading today's complex groups and organisations, where followers not only seek an inspirational leader to help them through an uncertain environment, but also want to be challenged and to feel empowered, if they are to be loyal and perform well (Bass \& Riggio, 2006). Employees who experience a talent management system that is based on an inclusive or stable philosophy are likely to feel supported and valued by their organisation because they work in surroundings that are generally appreciative of their talents. Consequently, such employees make positive attributions regarding the goals of talent management (Meyers \& Van Woerkom, 2014). The concept of engagement has been researched and conceptualised as the 'harnessing of organisation members' selves to their work roles: in engagement, people employ and express themselves physically, cognitively, and emotionally and mentally during role performances' (Kahn, 1990). The results of the research done by Kahn (1990) reflected that engaged employees put a great deal of effort into their work because they identify themselves with it.

A summary of the outcomes of the hypotheses is presented in Table 4

\section{Practical implications}

The complex environment that the automotive industry faces today highlights the importance of transformational leadership, talent management and work engagement for

TABLE 4: Hypotheses accepted/rejected.

\begin{tabular}{ll}
\hline Hypotheses & Accepted/rejected \\
\hline $\begin{array}{l}\text { Hypothesis 1: Talent management (performance planning and } \\
\text { motivational processes) will be positively related to } \\
\text { transformational leadership. }\end{array}$ & Accepted \\
$\begin{array}{l}\text { Hypothesis 2: Talent management (career development) will } \\
\text { be positively related to transformational leadership. }\end{array}$ & Accepted \\
$\begin{array}{l}\text { Hypothesis 3: Talent management (performance planning } \\
\text { and motivational processes) will be positively related to } \\
\text { work engagement (vigour). }\end{array}$ & Accepted \\
$\begin{array}{l}\text { Hypothesis 4: Talent management (career development) } \\
\text { will be positively related to work engagement (vigour). }\end{array}$ & Accepted \\
$\begin{array}{l}\text { Hypothesis 5: Talent management (performance planning } \\
\text { and motivational processes) will be positively related to work } \\
\text { engagement (dedication). }\end{array}$ & Accepted \\
$\begin{array}{l}\text { Hypothesis 6: Talent management (career development) } \\
\text { will be positively related to work engagement (dedication). }\end{array}$ & Accepted \\
$\begin{array}{l}\text { Hypothesis 7: Work engagement (vigour) will be positively } \\
\text { related to transformational leadership. }\end{array}$ & Rejected \\
$\begin{array}{l}\text { Hypothesis 8: Work engagement (dedication) will be } \\
\text { positively related to transformational leadership. }\end{array}$ & Rejected \\
$\begin{array}{l}\text { Hypothesis 9: Talent management will mediate } \\
\text { transformational leadership and work engagement. }\end{array}$ & Accepted \\
\hline
\end{tabular}

the effective management of organisations. This study investigated the relationship between transformational leadership, talent management and work engagement amongst artisans in the automotive industry. This study provides initial support for a complex relationship between transformational leadership, work engagement and talent management. As further research provides greater support, the development of greater validity between these variables could be used as a supplement to transformational leadership to handle the changing corporate environment effectively.

\section{Limitations of the study}

Although the current study yielded some interesting results, there are limitations that could negatively impact its generalisability because the study only reflects the views of artisans working in the automotive industry. Cross-sectional and survey research designs were used and can, therefore, not be generalised to other industries as in the case with the study of Mathafena and Grobler (2020). This necessitates repeated longitudinal research for this type of study. The results of the study could be explained better if both quantitative and qualitative methods had been employed in the study. There is an opportunity to explore a pessimistic view that might highlight many intervention opportunities with the next survey process and qualitative research.

\section{Recommendations}

In the automotive industry, transformational leadership is needed to guide artisans so that they share goals, attitudes, values, and work towards the achievement of organisational strategies (Gautam \& Enslin, 2019). These leaders also need to stimulate employees' work engagement through progressive policies and work practices (Decuypere \& Schaufeli, 2020). Policies and procedures should be reviewed to ensure better compliance towards artisans in this regard:

[O]rganisational executives should focus simultaneously on understanding the broader aspects of work engagement within an organisation as well as providing constant support to develop the leadership skills of managers, particularly transformational leadership skills. (Gautam \& Enslin, 2019, p. 139)

Lastly, a talent management strategy that includes transformational leadership and work engagement should be developed to guide the automotive industry on the way forward. Artisan development will take place through strategic processes that are shared at all levels of the organisation. Rewards and recognition will be measured by management with talent management as the mediator.

\section{Conclusion}

The purpose was to determine the relationship between talent management, transformational leadership and work engagement from an automotive artisan perspective within South Africa. 
The results showed that transformational leadership is negatively related to work engagement, talent management is positively related to transformational leadership and work engagement is negatively related to transformational leadership. Lastly, talent management is a mediator between transformational leadership and work engagement. These results could assist managers to become transformational leaders in order to properly manage talent amongst artisans in the South African automotive industry so that these artisans' work engagement can improve. A talent management strategy that includes transformational leadership and work engagement should, therefore, be developed to guide the automotive industry on the way forward.

\section{Acknowledgements Competing interests}

The authors declare that they have no financial or personal relationships that may have inappropriately influenced them in writing this article.

\section{Authors' contributions}

Dr Smit did the research together with analytical analysis of the researched data and the development of a framework determining the mediating factor. Prof. Schultz was the supervisor for this topic. Dr van Hoek was the co-supervisor to the topic.

\section{Funding information}

This research received no specific grant from any funding agency in the public, commercial or not-for-profit sectors.

\section{Data availability}

The data were recorded on an Excel spreadsheet and captured into the SPSS V23 software package. The data were kept electronically as well as in hard copy. The original completed questionnaires were also stored.

\section{Disclaimer}

The views and opinions expressed in this article are those of the authors and do not necessarily reflect the official policy or position of any affiliated agency of the authors.

\section{References}

Amor, A.M., Vázquez, J.P.A., \& Faíña, J.A. (2020). Transformational leadership and work engagement: Exploring the mediating role of structural empowerment. European Management Journal, 38(1), 169-178. https://doi.org/10.1016/j.emj.2019.06.007

Atiku, S.O., \& Anane-Simon, R. (2020). Leadership and innovative approaches in higher education. In N. Baporikar, \& M. Sony (Eds.), Quality managemen principles and policies in higher education (pp. 83-100). Hershey, PA: IGI Global.

Avolio, B.J., Bass, B.M., \& Jung, D.I. (1999). Re-examining the components of transformational and transactional leadership using the multifactor leadership. Journal of Occupational and Organizational Psychology, 72(4), 441-462. https:// doi.org/10.1348/096317999166789

Avolio, B.J., Waldman, D.A., \& Yammarino, F.J. (1991). Leading in the 1990s: The four I's of transformational leadership. Journal of European Industrial Training, 15(4), 9-16. https://doi.org/10.1108/03090599110143366

Axelrod, B., Handfield-Jones, H., \& Michaels, E. (2002). A new game plan for C players. Harvard Business Review, 80(1), 80-88.
Bakker, A.B., \& Albrecht, S. (2018). Work engagement: Current trends. Career Development International, 23(1), 4-11. https://doi.org/10.1108/CDI-11-20170207

Bakker, A.B., Albrecht, S.L., \& Leiter, M.P. (2011). Key questions regarding work engagement. European Journal of Work and Organizational Psychology, 20(1), 4-28. https://doi.org/10.1080/1359432X.2010.485352

Bakker, A.B., Demerouti, E., \& Sanz-Vergel, A.I. (2014). Burnout and work engagement: the JD-R approach. Annual Review of Organizational Psychology and Organizational Behavior, 1(1), 389-411. https://doi.org/10.1146/annurevorgpsych-031413-091235

Bakker, A.B., \& Leiter, M.P. (2010). Work engagement: A handbook of essential theory and research. Washington, DC: Psychology Press.

Bass, B.M., \& Riggio, R.E. (2006). Transformational leadership. Mahwah, NJ: Psychology Press.

Botma, Y., Greeff, M., Mulaudzi, F.M., \& Wright, S.C.D. (2010). Research in health sciences (1st ed.). Cape Town: Pearson Education.

Breevaart, K., Bakker, A.B., Hetland, J., Demerouti, E., Olsen, O.K., \& Espevik, R. (2014). Daily transactional and transformational leadership and daily employee Daily transactional and transformational leadership and daily employee
engagement. Journal of Occupational and Organizational Psychology, 87(1), 138-157. https://doi.org/10.1111/joop.12041

BusinessTech. (2021). South Africa's motoring industry has big plans. Retrieved from https://businesstech.co.za/news/motoring/476620/south-africas-motoringindustry-has-big-plans/

Chigbu, B.I., \& Nekhwevha, F.H. (2020). The extent of job automation in the automobile sector in South Africa. Economic and Industrial Democracy, 1-12. https://doi.org/10.1177/0143831X20940779

Church, A. (2013). Engagement is in the eye of the beholder: Understanding differences in the OD vs. talent management mindset. OD Practitioner, 45(2), $42-48$.

Decuypere, A., \& Schaufeli, W. (2020). Leadership and work engagement: Exploring explanatory mechanisms. German Journal of Human Resource Management, 34(1), 69-95. https://doi:10.1177/2397002219892197

Downton, J.V. (1973). Rebel leadership: Commitment and charisma in the revolutionary process. New York, NY: Free Press.

Gautam, A., \& Enslin, E. (2019). Transformational leadership and work engagement in the automotive retail industry: A study of South Africa. International Business Research, 12(5), 133-141. https://doi.org/10.5539/ibr.v12n5p133

Ghafoor, A., Qureshi, T.M., Khan, M.A., \& Hijazi, S.T. (2011). Transformational leadership, employee engagement and performance: Mediating effect of psychological ownership. African Journal of Business Management, 5(17), 7391-7403. https://doi.org/10.5897/AJBM11.126

Gonfa, B.D. (2019). Review on components of transformational leadership. Arabian Journal of Business and Management Review, 9(3), 1-5.

Hair, J.F., Jr., Sarstedt, M., Hopkins, L., \& Kuppelwieser, G. (2014). Partial least squares structural equation modeling (PLS-SEM): An emerging tool in business research. European Business Review, 26(2), 106-121. https://doi.org/10.1108/EBR-102013-0128

Hamidianpour, F., Esmaeilpour, M., \& Mashayekh, S. (2016). Studying the effect of transformational leadership style on organizational culture change. Journal of Academy of Business and Economics, 16(2), 7-24. https://doi.org/10.18374/ JABE16-2.1

Hayati, D., Charkhabi, M., \& Naami, A. (2014). The relationship between transformational leadership and work engagement in governmental hospitals nurses: A survey study. SpringerPlus, 3(1), a25. https://doi.org/10.1186/2193-1801-3-25

Hayward, B.A. (2005). Relationship between employee performance, leadership and emotional intelligence in a South African parastatal organisation. Unpublished master's thesis. Grahamstown: Rhodes University.

Hoch, J.E., Bommer, W.H., Dulebohn, J.H., \& Wu, D. (2018). Do ethical, authentic, and servant leadership explain variance above and beyond transformational leadership? A meta-analysis. Journal of Management, 44(2), 501-529. https:// doi.org/10.1177/0149206316665461

Hoole, C., \& Bonnema, J. (2015). Work engagement and meaningful work across generational cohorts. SA Journal of Human Resource Management/SA Tydskrif vir Menslikehulpbronbestuur, 13(1), Art. \#681, 11 pages. https://doi.org/10.4102/ sajhrm.v13i1.681

Hufkie, B. (2021). Essential employee knowledge management and re-skilling within the 4 ir in the South African automotive industry towards 2030. MA thesis. Port Elizabeth: Nelson Mandela University.

Ishayama, N. (2021). The impact of the talent management mechanism and selfperceived talent status on work engagement: the case of Japan. Asia Pacific Business Review, 1-19. https://doi.org/10.1080/13602381.2021.1905410

Johnson, C. (2015). New frontiers in talent management. HR Future, 6(1), 28-30.

Kahn, W.A. (1990). Psychological conditions of personal engagement and disengagement at work. Academy of Management Journal, 33(4), 692-724. https://doi.org/10.5465/256287

Khorshid, S., \& Pashazadeh, A. (2014). The impact of transformational leadership on organizational learning capabilities with respect to the mediating role of organizational intelligence. Transformational Leadership Journal, 11(1), 1-28.

Lai, F.-Y., Tang, H.-C., Lu, S.-C., Lee, Y.-C., \& Lin, C.-C. (2020). Transformational leadership and job performance: The mediating role of work engagement. SAGE Open, 10(1). https://doi.org/10.1177\%2F2158244019899085

Leedy, P.D., \& Ormrod, J.E. (2016). Practical research: Planning and design (11th ed.). Boston, MA: Pearson Education. 
Lewis, R.E., \& Heckman, R.J. (2006). Talent management: A critical review. Human Resource Management Review, 16(12), 139-154.

Louw, L., Muriithi, S.M., \& Radloff, S. (2017). The relationship between transformational leadership and leadership effectiveness in Kenyan indigenous banks. SA Journal of Human Resource Management/SA Tydskrif vir Menslikehulpbronbestuur, 15(0), a935. https://doi.org/10.4102/sajhrm.v15i0.935

Mathafena, R.B., \& Grobler, A. (2020). The effectiveness of human resources practices in driving proactive experimentation and risk-taking work behaviours in organisations. SAJournalofHuman Resource Management/SATydskrifvirMenslikehulpbronbestuu, 18(0), a1259. https://doi.org/10.4102/sajhrm.v18i0.1259

Mercer, S.R. (2005). Best-in-class leadership. Leadership Excellence, 22(3), 17.

Mey, M.R., Poisat, P., \& Stindt, C. (2021). The influence of leadership behaviours on talent retention: An empirical study. SA Journal of Human Resource Management/ SA Tydskrif vir Menslikehulpbronbestuur, 19(0), a1504. https://doi.org/10.4102/ sajhrm.v19i0.1504

Meyers, M.C., \& Van Woerkom, M. (2014). The influence of underlying philosophies on talent management: Theory, implications for practice, and research agenda. Journa of World Business, 49(2), 192-203. https://doi.org/10.1016/j.jwb.2013.11.003

Mittal, S., \& Dhar, R.L. (2015). Transformational leadership and employee creativity: Mediating role of creative self-efficacy and moderating role of knowledge sharing. Management Decision, 53(5), 894-910. https://doi.org/10.1108/MD-07-2014-0464

Nunnally, J.C. (1978). Psychometric theory (2nd ed.). New York, NY: McGraw-Hill.

Ogbari, M.E., Onasanya, Y.A., Ogunnaike, O.O., \& Kehinde, O.J. (2018). Talent management as a determinant of firm performance: A conceptual approach. management as a determinant of firm perform
Business \& Social Sciences Journal, 3(1), 21-32.

Onyango, W.P. (2015). Effects of transformational leadership styles on talent management: A case of micro, small and medium size enterprises in Migori County, Kenya. Journal of Poverty, Investment and Development, 10, 51-59.

Pallant, J. (2005). SPSS survival manual. Crows Nest: Allen \& Unwin.

Poisat, P., Mey, M.R., \& Sharp, G. (2018). Do talent management strategies influence the psychological contract within a diverse environment?. SA Journal of Human Resource Management/SA Tydskrif vir Menslikehulpbronbestuur, 16(0), a1044. https://doi.org/10.4102/sajhrm.v16i0.1044

Rhodes, C., \& Fletcher, S. (2013). Coaching and mentoring for self-efficacious leadership in schools. International Journal of Mentoring and Coaching in Education, 2(1), 47-63. https://doi.org/10.1108/20466851311323087

Saks, A.M., \& Gruman, J.A. (2017). Human resource management practices and employee engagement. In P. Sparrow \& C.L. Cooper (Eds), A research agenda for human resource management (pp. 95-113). Cheltenham: Edward Elgar.

Savarimuthu, A., \& Jothi, D.A. (2020). Talent management: A strategy for employee engagement. International Research Journal of Management Sociology \& Humanities, 10(12), 134-140.

Schaufeli, W.B., Bakker A.B., \& Salanova, M. (2006). The measurement of work engagement with a short questionnaire: A cross-national study. Educational and Psychological Measurement, 66(4):701-716. https://doi.org/10.1177/0013164405282471

Schaufeli, W.B. (2013). What is engagement? In C. Truss, K. Alfes, R. Delbridge, A Shantz, \& E. Soane (Eds.), Employee engagement in theory and practice (pp. 2657-2669). London: Routledge.

Schaufeli, W.B., \& Bakker, A.B. (2010). Defining and measuring work engagement: Bringing clarity to the concept. In A.B. Bakker \& M.P. Leiter (Eds.), Work engagement: A handbook of essential theory and research (pp. 10-24). New York engagement: $A$ hand
NY: Psychology Press.

Schaufeli, W.B., Martinez, I.M., Pinto, A.M., Salanova, M., \& Bakker, A.B. (2002a) Burnout and engagement in university students: A cross-national study. Journal of Burnout and engagement in university students: A cross-national study. Journal of
Cross-Cultural Psychology, 33(5), 464-481. https://doi.org/10.1177/002202 2102033005003

Schaufeli, W.B., Salanova, M., Gonzáles-Romá, V., \& Bakker, A.B. (2002b). The measurement of engagement and burnout: $A$ two sample confirmatory factor analytic approach. Journal of Happiness Studies, 3, 71-92. https://doi. analytic approach. Journal of

Schweyer, A. (2004). Talent management systems: Best practices in technology solutions for recruitment, retention, and workforce planning. Toronto: Wiley.
Shanaz, A.T., Dlvin, S.M., \& Vala, M.A. (2020). The underpinning theories of human resource management course. Retrieved from https://www.researchgate.net/ resource management course. Retrieved from https://www.researchgate.net/ Management_Course_Advance_Human_Resource_Management_Prepared

Sharma, M.G., \& Naude, M.J. (2021). Interdependence analysis of supplier relationship challenges in the South African automotive industry. Journal of Global Operations and Strategic Sourcing, 14(3), 438-453. https://doi.org/10.1108/ JGOSS-01-2020-0005

Shikweni, S., Schurink W., \& Van Wyk, R. (2019). Talent management in the South African construction industry. SA Journal of Human Resource Management/SA Tydskrif vir Menslikehulpbronbestuur, 17(0), a1094. https://doi.org/10.4102/ sajhrm.v17i0.1094

Sonnentag, S. (2017). A task-level perspective on work engagement: A new approach that helps to differentiate the concepts of engagement and burnout. Burnout Research, 5, 2-20. https://doi.org/10.1016/j.burn.2017.04.001

Sopiah, S., Kurniawan, D.T., Nora, E., \& Narmaditya, B.S. (2020). Does talent management affect employee performance?: The moderating role of work engagement. The Journal of Asian Finance, Economics, and Business, 7(7), 335-341. https://doi.org/10.13106/jafeb.2020.vol7.no7.335

StatsSA. (2021). What is GDP and its impact? Retrieved from http://www.statssa.gov. $\mathrm{za} / \mathrm{p}=1143$

Steinmann, B., Klug, H.J.P., \& Maier, G.W. (2018). The path is the goal: How transformational leaders enhance followers' job attitudes and proactive behaviour. Frontiers in Psychology, 9, 2338. https://doi.org/10.3389/fpsyg.2018.02338

Swanwick, T. (2017). Leadership theories and concepts. In T. Swanwick \& J. McKimm (Eds.), ABC of clinical leadership (pp. 9-13). Hoboken, NJ: Wiley-Blackwell.

Taris, T.W., Ybema, J.F., \& Van Beek, I. (2017). Burnout and engagement: Identical twins or just close relatives? Burnout Research, 5, 3-11. https://doi.org/10.1016/j. burn.2017.05.002

Teti, T.N. (2016). Learning experiences of female artisans in the automotive industry. Master of Management. School of Governance, Johannesburg: University of Witwatersrand.

Tims, M., Bakker, A.B., \& Xanthopoulou, D. (2011). Do transformational leaders enhance their followers' daily work engagement? The Leadership Quarterly, 22(1), 121-131. https://doi.org/10.1016/j.leaqua.2010.12.011

Toka, M.F., \& Hamida, A.S.M. (2020). Examining the relationship between talent management practices, work Engagement and intention to quit of academic staff: Insights from Egyptian Faculties of Tourism and Hotels. International Journal of Hospitality \& Tourism Systems, 13(1), 1-12.

Tuckey, M.R., Bakker, A.B., \& Dollard, M.F. (2012). Empowering leaders optimize working conditions for engagement: A multilevel study. Journal of Occupational Health Psychology, 17(1), 15-27. https://doi.org/10.1037/a0025942

Van Hoek, C.E. (2014). A competitive talent management strategy for a natural resources mining company in selected countries in Africa. Unpublished doctoral thesis. Pretoria: Tshwane University of Technology.

Van Rooyen, E.J., \& Whittle, C. (2011). Talent management as a key imperative for leadership development. Journal of Public Administration, 46(3), 1039-1054.

Walker, J.W., \& Larocco, J.M. (2002). Talent pools: The best and the rest. Human Resource Planning, 25(3), 12-14.

Wetzels, M., Odekerken-Schröder, G., \& Van Oppen, C. (2009). Using PLS path modeling for assessing hierarchical construct models: Guidelines and empirica illustration. MIS Quarterly, 33(1), 177-195. https://doi.org/10.2307/20650284

Widodo, W., \& Mawarto, M. (2020). Investigating the role of innovative behavior in mediating the effect of transformational leadership and talent management on performance. Management Science Letters, 10(2020), 2175-2182. https://doi. org/10.5267/j.msl.2020.3.019

Wildschut, A., \& Ralphs, G. (2016). Artisans and technicians in South Africa: What the future holds. HSRC Review. Retrieved from http://www.hsrc.ac.za/en/researchdata/view/8206

Yahya, K., Tan, F., \& Tay, L. (2017). The power of Ability-Motivation-Opportunity enhancing human resource management practices on organizational ethical climate. International Journal of Business and Society, 18(3), 547-562. https://doi. org/10.33736/ijbs.3146.2017 